\title{
Hemeroteca Digital
}

\author{
Efraim S. Leite Filho ${ }^{1}$, João O. Bovoloni Falavigna ${ }^{1}$, Adriano S. De Lima ${ }^{1}$ \\ ${ }^{1}$ Universidade Tiradentes (UNIT) - Aracaju, SE - Brasil \\ efraimleite@gmail.com, joaootaviobf21@gmail.com, adrianoslegmail.com
}

ABSTRACT "Hemeroteca Digital" is intended to be a digital document management system of the "Diários Oficiais do Estado de Sergipe", digitizing and making them available to the general public. Besides the management process, a website was created to give the public a means of access for it.

RESUMO O projeto Hemeroteca Digital tem como propósito ser um sistema de gestão documental dos Diários Oficiais do Estado de Sergipe, digitalizandoos de forma a se tornarem mais acessíveis ao público. Além do processo de gestão, foi criado um site de acesso aos documentos digitalizados.

\section{Introdução}

Instituições como a Universidade de Harvard, a Universidade de Cambridge e o Instituto de Massachusetts possuem acervos digitalizados e acessíveis a usuários do mundo inteiro. Iniciativas como o Projeto Gutenberg também contribuíram com o acesso à literatura, esse disponibilizando em sua base de dados livros cujos direitos autorais tenham expirado ou foram concedidos pelos autores (LEVACOV; 1997).

Tendo em vista a demanda gerada pela era digital e mudanças ocorridas na legislação brasileira, como a lei no 12.527/2011 que obriga órgãos públicos e empresas sem fins lucrativos a disponibilizar a qualquer pessoa, física e jurídica, o acesso a informações públicas, o projeto Hemeroteca Digital tem como objetivo desenvolver um produto de gestão de documentos. Os documentos trabalhados foram Diários Oficiais do Estado de Sergipe, que contém informações como editais de concursos públicos, portarias de nomeação e exoneração para cargos públicos, licitações e até mesmo, por um dado período, notícias cotidianas.

\section{Descrição do Aplicativo e Contribuição Tecnológica}

Foram desenvolvidos dois produtos distintos: um conjunto de processos capaz de digitalizar, manipular e tornar acessível as informações dos documentos ainda não 
digitalizados e um site que servirá de acesso público a estes diários. O site protótipo está disponível no link "http:/gpitic.tech/hemeroteca/"(Hemeroteca Digital), com o código online no GitHub "https://github.com/gomesrocha/Hemeroteca".

Como pode ser visto no protótipo acessível pelo link acima, foi criado um mecanismo de busca, em que o usuário pode buscar um diário oficial por sua data e por termos, palavras ou C.P.F.s na base inteira disponível ou somente num dado intervalo de tempo. Disponível para testes, o ano 2011 já está na base de dados online, mas estão digitalizados diários de 2011 a metade do ano 2000.

\section{Conclusão e Perspectivas Futuras}

Dessa maneira, a hemeroteca digital permite uma maior acessibilidade às informações públicas, seja do ponto de vista pessoal, como entrada na aposentadoria ou promoção na carreira, histórico, por conter fatos de eventos como da $2^{\mathrm{a}}$ Guerra Mundial, ou fiscalizador, permitindo a qualquer um avaliar o desempenho do Estado.

Existe uma perspectiva de que uma vez que o sistema seja colocado em produção e comprovada a sua eficácia, o modelo seja replicado em outros órgãos públicos, como forma de suprir a carência de informações disponíveis online e aprimorar a gestão dos acervos mantidos pelos estados.

\section{Referências}

LEVACOV, Marília. Bibliotecas virtuais:(r) evolução?. Ciência da Informação, v. 26, n. 2, 1997.

Lei no 12.527/2011 "Lei do Acesso à Informação", http://www.planalto.gov.br/ccivil_03/_ato2011-2014/2011/lei/112527.htm;

Acesso em: 04/05/2018. 